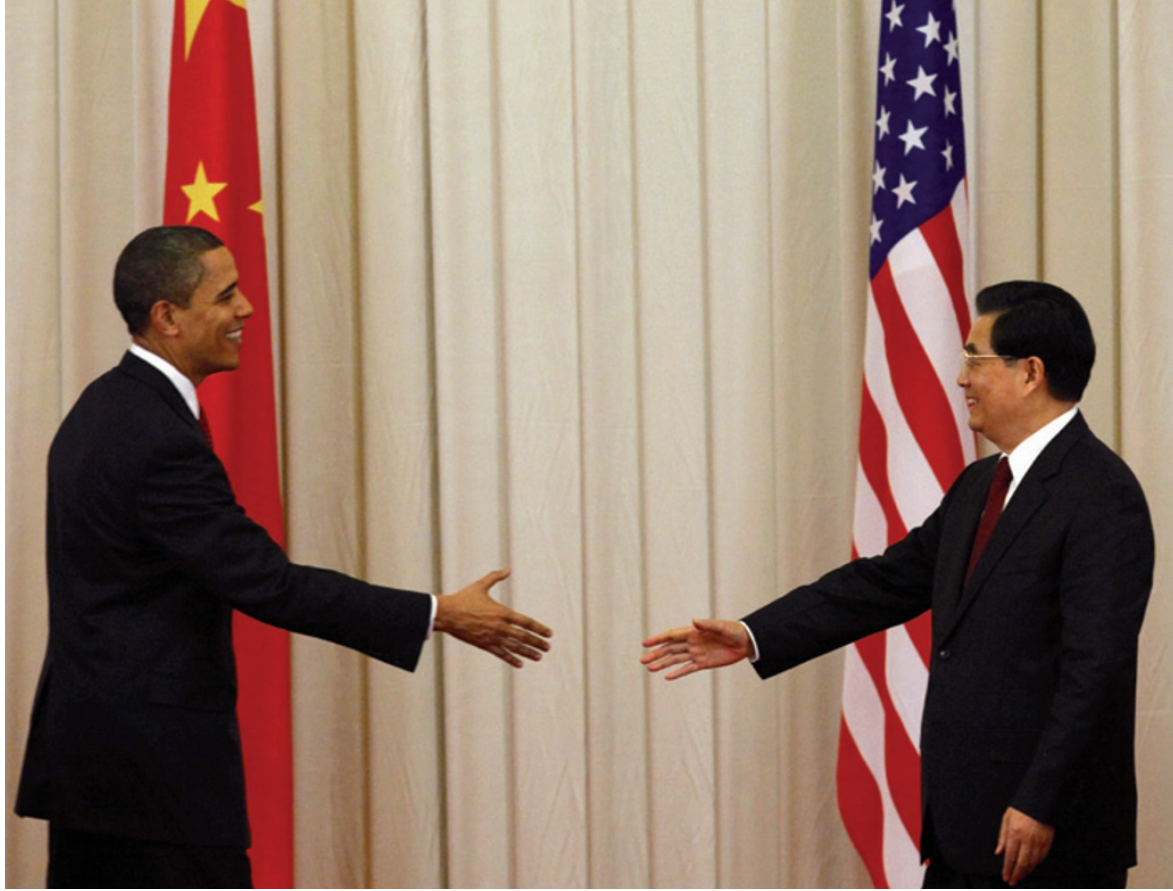

Presidents Barack Obama and Hu Jintao meeting in 2009. Space security was on the agenda.

\title{
US and China need contact, not cold war
}

\author{
Attempts to isolate the Chinese space community \\ undermine US interests, says Gregory Kulacki.
}

$\mathrm{T}$ his April, a US congressman used budget negotiations to ram through a potentially unconstitutional assault on the president's ability to conduct scientific diplomacy. A bill was passed stipulating that, until September 2011 at least, no appropriated funds may be used by NASA or the White House Office of Science and Technology Policy (OSTP) "to develop, design, plan, promulgate, implement, or execute a bilateral policy, program, order, or contract of any kind to participate, collaborate, or coordinate bilaterally in any way with China".

The move, instigated by Representative Frank Wolf (Republican, Virginia), chair of the commerce, justice and science subcommittee of the House appropriations committee, which funds NASA and the OSTP, is part of a decades-old congressional tradition of concerns about China's space programme. Nevertheless, this latest shot has wideranging implications. It has already led to the suspension of a geodynamics research project between the Chinese Academy of Sciences and NASA, for example. And it will impede ongoing bilateral negotiations on climate change and nuclear security that are part of the US-China Strategic and Economic Dialogue, a high-level forum established by presidents Barack Obama and $\mathrm{Hu}$ Jintao in 2009. My experience working in China for the Union of Concerned Scientists suggests that the ban will have a chilling effect on both government-funded scientific cooperation and on non-governmental activities.

The ban should be lifted. The progress of Chinese space activity during the previous US administration suggests that the prohibitions that have stifled Sino-American scientific cooperation for decades have not achieved their aims, and have arguably been counterproductive. China has shown that it has the talent and resources to go it alone. The sanctions have only severed links between the countries and made a new generation of Chinese intellectuals resentful and suspicious of the United States. And they stand in contrast to the tradition of scientists strengthening diplomatic relations.

There are signs that things could change. In 2009, Hu and Obama signed a joint statement to "enhance security in outer space" by "expanding discussions on space science cooperation". NASA administrator Charles Bolden visited Chinese launch facilities in October 2010, and presidential science adviser and OSTP director John Holdren has travelled to China three times in the past two years to discuss US-Chinese scientific and technical cooperation in many areas, including space science and exploration. Although no concrete programmes emerged from these travels, a second joint statement was signed in January 2011, committing the two countries to "deepen dialogue and exchanges in the field of space" and to "continue discussions on opportunities for practical future cooperation in the space arena, based on principles of transparency, reciprocity, and mutual benefit".

Wolf's bill, however, aims to prevent the Obama administration from implementing this statement. Holdren questioned the constitutionality of the ban when he testified before Wolf's subcommittee. He said that the Department of Justice had advised that the language in the resolution "should not be read as prohibiting interactions that are part of the president's constitutional authority to conduct negotiations". Representative John Culberson (Republican, Texas) accused Holdren of planning to violate the law and threatened legal and financial reprisals. He questioned Holdren about Chinese spies at the OSTP and NASA, and claimed that Holdren was "blindly ignoring the threat posed by China".

Why do members of Congress fear that advocates of scientific cooperation such as Holdren are naively helping China to win a new cold war?

\section{SHUTTLE DIPLOMACY}

The US-Chinese relationship in space began with cold-war intrigue. In 1950, the US government detained the Chinese-born rocket scientist Qian Xuesen on suspicion of communist sympathies. Qian was a US citizen with top-security clearance who served as director of the Jet Propulsion Laboratory at the California Institute of Technology in Pasadena. The charges were never substantiated. Under virtual house arrest, his career crumbling, Qian returned to China in 1955, where he spent the rest of his career leading China's efforts to develop ballistic missiles and space-launch vehicles. To this day, Chinese American scientists working for the US government do so under suspicions created by the legacy of this affair.

In 1979, diplomatic relations between the United States and China were normalized. Scientific and technological cooperation then became a tool of US military policy, as the United States sought to play China off against the Soviet Union. In 1984, President Reagan travelled to what he later described as "so-called communist China" 
to consolidate an extensive programme of scientific exchanges, including technical support for the modernization of China's armed forces.

Relations warmed further in 1986, when the US space-shuttle fleet was grounded by the Challenger disaster. The Reagan administration agreed to let US satellite manufacturers contract with China to arrange much-needed space-launch services. But after Chinese troops opened fire on unarmed protesters in the Tiananmen Square massacre of 1989, Congress imposed sanctions prohibiting those launches and exports of space and nuclear technology. These sanctions are still in effect, giving weight to arguments by some that the US-China Joint Statements of 2009 and 2011 go against congressional wishes and challenge congressional authority.

From the late 1980s to the early 1990s, President George H. W. Bush granted waivers of these sanctions, allowing the United States to use Chinese launches. During his campaign for presidency, Bill Clinton accused Bush of "coddling dictators". But after his election, he too issued waivers and even simplified the waiverapproval process. In 1998, The New York Times columnist William Safire accused President Clinton of selling space technology to the Chinese military in exchange for campaign contributions, and Congress launched an investigation. Administration officials admitted that the waivers were politi$\mathrm{cal}$ - they were an incentive for China to honour its agreement not to sell missile technology to Iran and Syria. No charges were filed, but the issue of cooperation with China in space became highly politicized.

Then, in February 1996, a US communications satellite was destroyed during a failed Chinese launch. It was reported that US workers had given Chinese officials investigating the accident sensitive technical information with potential military uses. This too led to an investigation, which figured prominently in the final report of a select House committee on commercial and scientific relations between the United States and China. The 1999 Cox Report, named after chairman Christopher Cox (Republican, California), ended the satellite launches and led to tighter restrictions on all scientific and technical cooperation with China. George W. Bush did not challenge these restrictions.

China took them in its stride, increasing domestic spending on space and completing its first human space flight in October 2003. When the United States pressured Europe to limit Chinese participation in the Galileo project, the European rival to the Global Positioning System, China began building its own system. US refusals to allow China to join the
International Space Station prompted Chinese leaders to green-light a national spacestation plan. In January 2007, Chinese tests of anti-satellite weaponry included the dramatic destruction of a defunct Chinese weather satellite used for target practice, scattering debris that threatens to strike other satellites and the International Space Station. In sum, the sanctions meant to inhibit Chinese progress in space have done no such thing.

\section{COMMON GROUND}

Some see a moral argument behind the bans on US-China collaboration, arguing that China's human-rights record necessitates a certain distance. Wolf is one such person. He challenged Holdren to justify cooperation with a regime still guilty of the same human-rights abuses that precipitated the Tiananmen sanctions. Holdren explained that the administration's pursuit of scientific and technological cooperation was not an endorsement of the Chinese government or a reward for good behaviour, but was necessary to address complicated threats to US

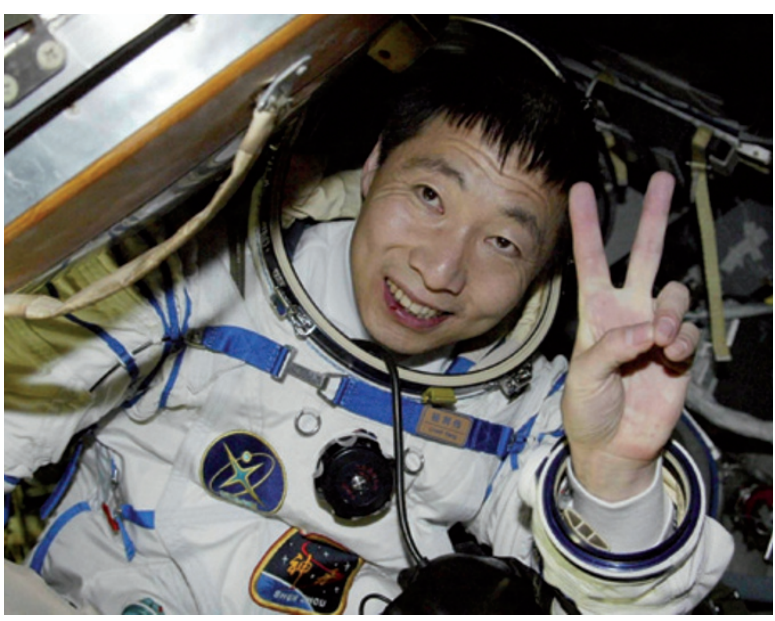

Yang Liwei piloting the first manned Chinese space mission in 2003

interests, including climate change, nuclear terrorism and space debris. These are problems that require international solutions, and if China fails to address them it will harm the US public.

Scientific diplomacy has long brought together individuals interested in solving problems, who share a common language and methodology that helps them to overlook national and cultural differences. Of course, scientists are not immune to economic interests, bureaucratic entanglements and political passions, but my personal and professional experience suggests that they are able to set them aside more easily than politicians, diplomats or soldiers.

The Union of Concerned Scientists has more than two decades of experience working with scientists from across the world on public-policy issues that require international scientific and technical cooperation, notably: the pursuit of nuclear disarmament; nuclear-power safety and security; and security in outer space. More than 100 Chinese scientists and engineers have participated in our annual Summer Symposiums on Science and World Affairs, and many have gone on to hold important positions in Chinese institutes. The China Project that I manage for the union has used these relationships to expand dialogue and pursue joint research on the contentious security issues that have long divided Chinese and US scientists.

In the process, we have established relationships with China's defence-science community that our counterparts in government cannot. We have used these relationships to ease Chinese anxieties about US missile defences, US discussions of developing new nuclear weapons, and the Pentagon's overblown rhetoric about 'space control.' We are starting discussions aimed at helping Chinese scientists to make decisions that reduce the risks of nuclear power. Scientists with access to good support networks and information can make a positive difference to government policies, or at least try to. The Union of Concerned Scientists has learned that the January 2007 anti-satellite test was approved in part thanks to distorted representations of data on space debris provided by the Chinese military. We watched with admiration as our Chinese research colleagues risked their careers to provide their government with more reliable information.

US scientific and technological cooperation is unlikely to reform China's oppressive political system. But experience shows that it can contribute to mitigating some of the dangers to US citizens. It can also foster communication and understanding, setting the stage for cooperation on issues that require international solutions.

Wolf is to be commended for his support for human rights, and congressional concerns about US-China rivalry are understandable. But President Obama's decision to use scientific cooperation as an instrument of diplomacy is not only his constitutional prerogative, it is the best way to advance US interests. The two joint statements and the efforts of NASA and the OSTP are hopeful signs that the Obama administration is pursuing a healthy approach to collaboration. Gaining congressional support for such efforts requires a broader awareness of the constructive role that scientists can have in international relations.

Gregory Kulacki is a senior analyst and the China Project manager for the Union of Concerned Scientists.

e-mail:gkulacki@ucsusa.org 